
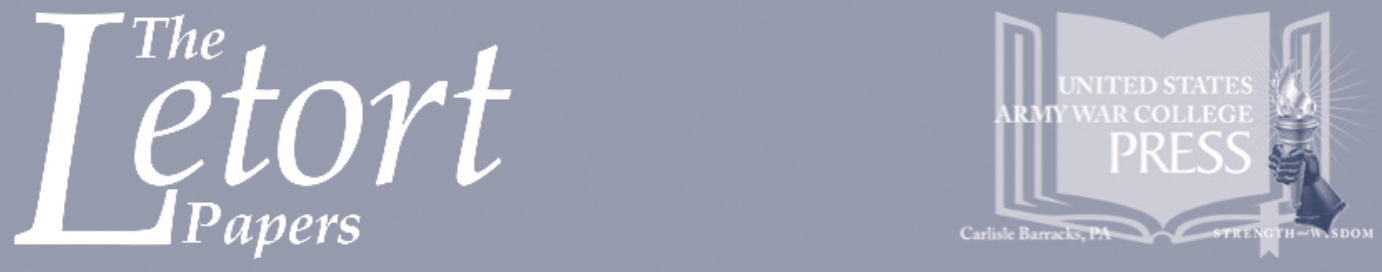

\title{
ANOTHER BRICK IN THE WALL: THE ISRAELI EXPERIENCE IN MISSILE DEFENSE
}

\section{Jean-Loup Samaan}

Strategic Studies Institute 


\section{Report Documentation Page}

Form Approved

OMB No. 0704-0188

Public reporting burden for the collection of information is estimated to average 1 hour per response, including the time for reviewing instructions, searching existing data sources, gathering and maintaining the data needed, and completing and reviewing the collection of information. Send comments regarding this burden estimate or any other aspect of this collection of information,

including suggestions for reducing this burden, to Washington Headquarters Services, Directorate for Information Operations and Reports, 1215 Jefferson Davis Highway, Suite 1204, Arlington

VA 22202-4302. Respondents should be aware that notwithstanding any other provision of law, no person shall be subject to a penalty for failing to comply with a collection of information if it

does not display a currently valid OMB control number.

\begin{tabular}{|c|c|c|}
\hline $\begin{array}{l}\text { 1. REPORT DATE } \\
\text { APR } 2015\end{array}$ & 2. REPORT TYPE & $\begin{array}{l}\text { 3. DATES COVERED } \\
\mathbf{0 0 - 0 0 - 2 0 1 5} \text { to 00-00-2015 }\end{array}$ \\
\hline \multirow{3}{*}{\multicolumn{2}{|c|}{$\begin{array}{l}\text { 4. TITLE AND SUBTITLE } \\
\text { Another Brick in the Wall: The Israeli Experience in Missile Defense }\end{array}$}} & 5a. CONTRACT NUMBER \\
\hline & & 5b. GRANT NUMBER \\
\hline & & 5c. PROGRAM ELEMENT NUMBER \\
\hline \multirow{3}{*}{\multicolumn{2}{|c|}{ 6. AUTHOR(S) }} & 5d. PROJECT NUMBER \\
\hline & & 5e. TASK NUMBER \\
\hline & & 5f. WORK UNIT NUMBER \\
\hline \multicolumn{2}{|c|}{$\begin{array}{l}\text { 7. PERFORMING ORGANIZATION NAME(S) AND ADDRESS(ES) } \\
\text { U.S. Army War College,Strategic Studies Institute, } \mathbf{4 7} \text { Ashburn } \\
\text { Drive,Carlisle,PA,17013-5010 }\end{array}$} & $\begin{array}{l}\text { 8. PERFORMING ORGANIZATION } \\
\text { REPORT NUMBER }\end{array}$ \\
\hline \multirow{2}{*}{\multicolumn{2}{|c|}{ 9. SPONSORING/MONITORING AGENCY NAME(S) AND ADDRESS(ES) }} & 10. SPONSOR/MONITOR'S ACRONYM(S) \\
\hline & & $\begin{array}{l}\text { 11. SPONSOR/MONITOR'S REPORT } \\
\text { NUMBER(S) }\end{array}$ \\
\hline
\end{tabular}

12. DISTRIBUTION/AVAILABILITY STATEMENT

Approved for public release; distribution unlimited

13. SUPPLEMENTARY NOTES

14. ABSTRACT

15. SUBJECT TERMS

16. SECURITY CLASSIFICATION OF:

\begin{tabular}{c|c|c|c|}
$\begin{array}{c}\text { a. REPORT } \\
\text { unclassified }\end{array}$ & $\begin{array}{c}\text { b. ABSTRACT } \\
\text { unclassified }\end{array}$ & $\begin{array}{c}\text { c. THIS PAGE } \\
\text { unclassified }\end{array}$ & $\begin{array}{c}\text { Same as } \\
\text { Report (SAR) }\end{array}$
\end{tabular}

\begin{tabular}{c|l}
$\begin{array}{c}\text { 18. NUMBER } \\
\text { OF PAGES } \\
\mathbf{6 1}\end{array}$ & 19a. NAME OF \\
&
\end{tabular}




\section{The United States Army War College}

The United States Army War College educates and develops leaders for service at the strategic level while advancing knowledge in the global application of Landpower.

The purpose of the United States Army War College is to produce graduates who are skilled critical thinkers and complex problem solvers. Concurrently, it is our duty to the U.S. Army to also act as a "think factory" for commanders and civilian leaders at the strategic level worldwide and routinely engage in discourse and debate concerning the role of ground forces in achieving national security objectives.
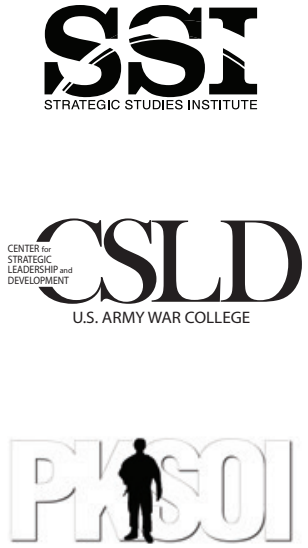

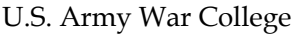

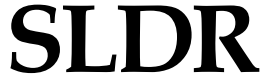

Senior Leader Development and Resiliency

The Strategic Studies Institute publishes national security and strategic research and analysis to influence policy debate and bridge the gap between military and academia.

The Center for Strategic Leadership and Development contributes to the education of world class senior leaders, develops expert knowledge, and provides solutions to strategic Army issues affecting the national security community.

The Peacekeeping and Stability Operations Institute provides subject matter expertise, technical review, and writing expertise to agencies that develop stability operations concepts and doctrines.

The Senior Leader Development and Resiliency program supports the United States Army War College's lines of effort to educate strategic leaders and provide well-being education and support by developing self-awareness through leader feedback and leader resiliency.

The School of Strategic Landpower develops strategic leaders by providing a strong foundation of wisdom grounded in mastery of the profession of arms, and by serving as a crucible for educating future leaders in the analysis, evaluation, and refinement of professional expertise in war, strategy, operations, national security, resource management, and responsible command.

The U.S. Army Heritage and Education Center acquires, conserves, and exhibits historical materials for use to support the U.S. Army, educate an international audience, and honor Soldiers-past and present. 


\section{STRATEGIC \\ STUDIES \\ INSTITUTE}

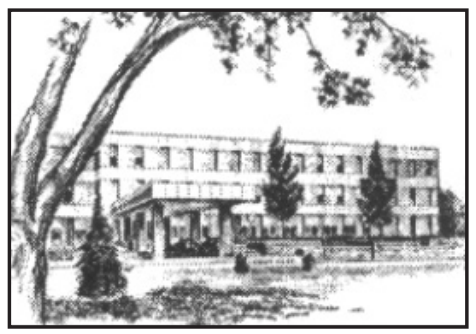

The Strategic Studies Institute (SSI) is part of the U.S. Army War College and is the strategic-level study agent for issues related to national security and military strategy with emphasis on geostrategic analysis.

The mission of SSI is to use independent analysis to conduct strategic studies that develop policy recommendations on:

- Strategy, planning, and policy for joint and combined employment of military forces;

- Regional strategic appraisals;

- The nature of land warfare;

- Matters affecting the Army's future;

- The concepts, philosophy, and theory of strategy; and,

- Other issues of importance to the leadership of the Army.

Studies produced by civilian and military analysts concern topics having strategic implications for the Army, the Department of Defense, and the larger national security community.

In addition to its studies, SSI publishes special reports on topics of special or immediate interest. These include edited proceedings of conferences and topically oriented roundtables, expanded trip reports, and quick-reaction responses to senior Army leaders.

The Institute provides a valuable analytical capability within the Army to address strategic and other issues in support of Army participation in national security policy formulation. 



\author{
Strategic Studies Institute \\ and \\ U.S. Army War College Press
}

\title{
ANOTHER BRICK IN THE WALL: \\ THE ISRAELI EXPERIENCE IN MISSILE DEFENSE
}

\author{
Jean-Loup Samaan
}

April 2015

The views expressed in this report are those of the author and do not necessarily reflect the official policy or position of the Department of the Army, the Department of Defense, or the U.S. Government. Authors of Strategic Studies Institute (SSI) and U.S. Army War College (USAWC) Press publications enjoy full academic freedom, provided they do not disclose classified information, jeopardize operations security, or misrepresent official U.S. policy. Such academic freedom empowers them to offer new and sometimes controversial perspectives in the interest of furthering debate on key issues. This report is cleared for public release; distribution is unlimited.

$* * * * *$

This publication is subject to Title 17, United States Code, Sections 101 and 105. It is in the public domain and may not be copyrighted. 
Comments pertaining to this report are invited and should be forwarded to: Director, Strategic Studies Institute and U.S. Army War College Press, U.S. Army War College, 47 Ashburn Drive, Carlisle, PA 17013-5010.

\section{$* * * * *$}

This manuscript was funded by the U.S. Army War College External Research Associates Program. Information on this program is available on our website, www.StrategicStudies Institute.army.mil, at the Opportunities tab.

$* * * * *$

All Strategic Studies Institute (SSI) and U.S. Army War College (USAWC) Press publications may be downloaded free of charge from the SSI website. Hard copies of this report may also be obtained free of charge while supplies last by placing an order on the SSI website. SSI publications may be quoted or reprinted in part or in full with permission and appropriate credit given to the U.S. Army Strategic Studies Institute and U.S. Army War College Press, U.S. Army War College, Carlisle, PA. Contact SSI by visiting our website at the following address: www.StrategicStudiesInstitute.army.mil.

$* * * * *$

The Strategic Studies Institute and U.S. Army War College Press publishes a monthly email newsletter to update the national security community on the research of our analysts, recent and forthcoming publications, and upcoming conferences sponsored by the Institute. Each newsletter also provides a strategic commentary by one of our research analysts. If you are interested in receiving this newsletter, please subscribe on the SSI website at www.StrategicStudiesInstitute.army.mil/newsletter.

ISBN 1-58487-675-1 


\section{FOREWORD}

Over the last years, missile defense has resurfaced as a major feature of the strategic debate in the United States and among its close allies. In 2010, the North Atlantic Treaty Organization Summit of Heads of State saw intense discussions among transatlantic partners on the strategic value of missile defense alongside the traditional deterrence means of the Alliance. But if these transatlantic debates are for the most part still speculative, for many years, one close American ally has already faced the concrete and immediate challenge of defending its territory against missiles and rockets - Israel.

As demonstrated during the last clashes between the Israeli Defense Forces and Palestinian factions (2012 and 2014), missile defense is now a pillar of Israel's strategic culture. Understanding this evolution demands an in-depth look at its political, military, and technical ramifications. That is the very purpose of this new monograph by Dr. Jean-Loup Samaan.

Based on archival research and numerous interviews with key players in Israel, Dr. Samaan provides us with one of the first comprehensive appraisals of Israel's experience in missile defense. He reminds us of the uncertain development of the Arrow program and the historical skepticism from the military establishment toward a defensive posture. He systematically puts the evolution of this enterprise into its regional context, describing meticulously the proliferation of arsenals by states and nonstate actors. Moreover, he highlights the key strategic issues that matter, and will 
continue to matter, not only for the Israeli but also for the U.S. defense community.

For this reason, the Strategic Studies Institute is pleased to offer this monograph on the Israeli Experience in Missile Defense and the manner in which it can impact U.S. national security interests.

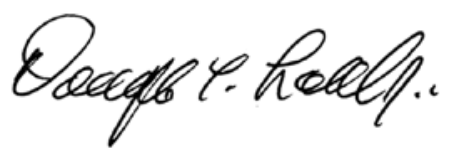

DOUGLAS C. LOVELACE, JR.

Director

Strategic Studies Institute and

U.S. Army War College Press 


\section{ABOUT THE AUTHOR}

JEAN-LOUP SAMAAN is a researcher for the Middle East Faculty at the North Atlantic Treaty Organization (NATO) Defense College in Rome, Italy. He is a member of the International Institute for Strategic Studies and the Project on Nuclear Issues of the Center for Strategic and International Affairs. His areas of expertise include Middle East strategic balance and Gulf security diplomacies, as well as cyber defense. He was a policy advisor at the French Ministry of Defense from 2008 to 2011, where he was responsible for several net assessment studies covering transatlantic military affairs. While working for the French Ministry of Defense (MoD), he participated in various French-American strategic foresight exercises with the National Intelligence Council as well as with the U.S. Air Force. From 2009 to 2011, he was also an adjunct lecturer in international security at the French Institute for Political Studies, Sciences Program, and gave lectures to civilian and military audiences in various countries. In 2006, he was a visiting scholar at Duke University, and from 2007 to 2008, he was a researcher at the RAND Corporation in Washington, DC. Dr. Samaan has authored three books and several academic articles for various international journals such as Survival, Orbis, Comparative Strategy, Turkish Policy Quarterly, Politique Etrangère, and Internationale Politik. He is a regular columnist for the E-magazine, Al Monitor. Dr. Samaan is a former student of Arabic at the French Institute of Oriental Languages and the French Institute for the Near East in Beirut, Lebanon. He graduated from the Institute for Political Studies in Grenoble, and holds a Ph.D. in political science from the University of Paris La Sorbonne. 



\section{SUMMARY}

Starting in the 1970s, the Arab states and Iran embarked on ballistic missile programs aimed at overcoming the Israeli military superiority gained through the past decades. At first, Israel kept relying on its traditional offensive doctrines that enabled the launching of preemptive campaigns that would swiftly move the battles to the territory its enemies. The country did start cooperating with the U.S. administration in the early-1980s as part of President Ronald Reagan's Strategic Defense Initiative, but it was a decision based on opportunism rather than on a sense of urgency. The real trigger for Israel's missile defense efforts was Saddam Hussein's use of ballistic missiles first against Iran (1985-88) and then against the Hebrew State itself (1991). This led to the building of Arrow, a highly sophisticated system aimed at intercepting ballistic missiles.

But soon another type of threat emerged: in the 1990s and the following decade, nonstate actors such as Hezbollah and Hamas rapidly acquired rockets and short-range missiles that changed the equation with the Israeli Defense Forces (IDF). In particular, Hezbollah's performance during the 2006 war called for a new response. In addition to Arrow, Israel then developed Iron Dome. This new system would soon become the most iconic system of Israel's military power as evidenced during Operation PILLARS OF DEFENSE (2012) and Operation PROTECTIVE EDGE (2014).

After having been looked at with scepticism, missile defense was now the object of political passion. This trend transcended Israel as the successes of Iron Dome were used by proponents of missile defense in the United States and in North Atlantic Treaty Orga- 
nization (NATO) countries. However, this passion frequently misreads the strategic meaning of Israel's enterprise. First, its military never conceived these systems as substitutes to its past offensive posture. Iron Dome or Arrow are mere complementary assets to the IDF. Moreover, there remain significant unknowns on topics such as the effectiveness of the systems in intercepting rockets and missiles or the extent to which they deter neighboring states and nonstates from investing in new arsenals. As a consequence, this calls for a cautious assessment of the Israeli experience and its potential lessons for U.S. and NATO's own efforts. 


\section{ANOTHER BRICK IN THE WALL: THE ISRAELI EXPERIENCE IN MISSILE DEFENSE}

\section{INTRODUCTION}

In recent years, the issue of missile defense has become one of the most prominent features of Israel's military debate. During the last military campaigns, such as Operation PILLAR OF DEFENSE (November 2012) and Operation PROTECTIVE EDGE (July 2014), missile defense systems like Iron Dome proved crucial against rockets targeting Israeli territory. As a result, they have attracted increasing political attention. Suddenly, missile defense left a domain reserved to engineers and military operators to be the object of discussion by politicians and defense intellectuals.

Against this backdrop, international media and policy circles now focus on Israel as the most advanced case to test the validity of missile defense. Countries like India and South Korea eye the Israeli systems as possible means to address their own security predicaments. The North Atlantic Treaty Organization (NATO), in particular, has dedicated a lot of attention to the question of Israeli experience in missile defense and the lessons to be drawn from it: the Alliance now looks at Israel's reliance on this form of defense as a possible reflection of how its own posture on the subject is evolving.

However, a careful study of Israel's experience with missile defense reveals a history that is quite distinct from the mainstream narrative. Although ballistic missile proliferation in the Middle East started in the 1970s, only a decade after that the Israeli military establishment embarked on the path to missile defense. Moreover, it was initially due to the 
opportunity to benefit from U.S. financial aid in the context of President Ronald Reagan's Strategic Defense Initiative (SDI). All along, the establishment of missile defense faced technical, financial, political, or doctrinal obstacles.

In that perspective, this monograph offers a detailed account of Israel's missile defense efforts. It stresses the regional events that triggered the development of Arrow or Iron Dome, but it also offers a look at the bureaucratic tensions that these new (and costly) systems produced. To this aim, the first section covers the first age of Israel's missile defense history with the rise of ballistic missiles in the region and, as a result, the advent of the Arrow system. The second section highlights how the spread of rockets and shortrange missiles to nonstate actors in the Middle East called for a new answer, which eventually was Iron Dome. Finally, the third section offers key findings at the level of strategic studies on the Israeli experience.

\section{BALLISTIC MISSILE PROLIFERATION AND THE ADVENT OF ARROW}

The root cause of Israel's missile defense enterprise can be traced back to the 1970s with the first wave of missile proliferation in the Middle East. The 6-day war of 1967 had marked the advent of Israel's military supremacy in the region. In particular, the way the Israelis decapitated the Egyptian Air Force on June 5 in only 3 hours engendered tremendous awe among the Arab states. By the early-1970s, Arab militaries came to the realization that strategic parity with the Hebrew State was out of sight, at least through conventional means. Such was the conclusion that led them, and primarily Egypt, to embark on missile programs. In 
other words, if Israeli air power was overwhelmingly superior, Arabs could only bypass their inferiority via missiles. As a result, Egypt launched its ballistic program in cooperation with the Union of Soviet Socialist Republics (USSR), and by 1973, Frog-7 missiles (70 kilometer [km] range) and Scud-Bs (300-km) went into service. In the midst of the 1973 war, Egypt fired three Scud-Bs that were aimed at destroying Israeli bridges along the Suez canal but none reached its target. ${ }^{1}$ Despite these inconclusive results, President Anwar al Sadat approved the further development of the arsenal. The Frog-7 was later upgraded with North Korean technological assistance and led to the Sakr-80. In the following decade, proliferation networks intensified, and Egypt was now on board with an ambitious project that associated Iraq and Argentina to build a 1000-km range missile named Badr-2000.

By the time Egypt had joined forces with Iraq and Argentina, Israel had started addressing the issue posed by these rising arsenals. But it would be a skewed observation to state that the Israelis merely answered the Arab efforts with the making of a missile shield. In the early-1980s, the first stages of Israel's missile defense enterprise were closely intertwined with those of the American project. It was only after Reagan's SDI was launched in 1983 that Israel started envisioning such a project.

On March 23, 1983, Reagan gave his seminal speech on the SDI. For him, missile defense was a means to render the logic of mutually assured destruction (MAD) obsolete. In his vision, it was profoundly immoral to ensure the citizens' safety through such a shaky principle as MAD, and, therefore, he considered the SDI a real imperative. In his speech, Reagan asked the question that drove his quest: "What if free people 
could live secure in the knowledge that ... we could intercept and destroy strategic ballistic missiles before they reached our own soil or that of our allies?"2 Although Reagan's speech made references to America's allies, the international reactions were lukewarm to say the least. Only the United Kingdom (UK), West Germany, and Israel accepted the offer to participate in SDI research and development programs. But Israel did it with extreme caution. To understand the Israeli cautious approach, one needs to put it into the context of the country's strategic culture.

Since the birth of Israel, its armed forces had relied on offensive doctrines rather than defensive ones. Starting in the late-1940s, Israel's strategic culture had been shaped by constraints such as the absence of strategic depth and scarce manpower that left the country at the mercy of protracted conflicts. Because of these conditions, long wars would put the existence of the state at risk. To bypass these elements, Israeli leaders opted for offensive doctrines, enabling the launching of preemptive campaigns that would swiftly move the battles to the territory of their enemies. Even though the reality of an existential threat coming from Arab conventional armies vanished after the 1967 war, this scenario still remained a key driver of Israeli military planning processes in the mid-1980s. ${ }^{3}$ In a 1989 book dedicated to the offense-defense debate in Israel, Ariel Levite stressed this strong inclination among military planners for an offensive posture:

this attitude is characterized by contempt for defensive operations, heavy emphasis on the ephemeral nature of the defensive battle, and a surprising degree of ignorance regarding the doctrinal characteristics or the internal logic of defensive operations. ${ }^{4}$ 
This explains the initial scepticism toward a weapon system presumed to rebalance resources from offensive to defensive means. Contrary to the Reaganian dream to build missile defense to render nuclear weapons obsolete, the Israeli calculus was driven by a mix of opportunism and pragmatism: All along, the government faced tremendous scepticism from a military establishment that saw missile defense as strategically misleading.

Despite resistance, U.S.-Israel cooperation started the year after Reagan's speech. The first step consisted of visits and exchanges between Israel's Research and Development Directorate (MAFAT) and the U.S. Strategic Defense Initiative Organization (SDIO), which was established in 1984. Interestingly, one of the strongest critics of Israel's participation in SDI was neither technologically nor doctrinally based, but politically based. Sceptics in Israel argued that such a move would antagonize the Soviet Union, which was explicitly the target of Reagan's project, and that Israel would diplomatically suffer from this alignment.

On May 5 1986, U.S. Secretary of Defense Caspar Weinberger and his Israeli counterpart, Yitzhak Rabin, signed a bilateral Memorandum of Understanding. U.S.-Israel cooperation was to exclude the most sensitive and classified realms of missile defense technologies. First projects were limited: a $\$ 100$ million contract was allocated to investigate a combined chemical and electrical propulsion scheme for projectiles fired by the railgun. ${ }^{5}$ Soon, the first director of SDIO, General James Alan Abrahamson, suggested to his Israeli counterparts that they start developing their own missile defense system that would address the specific threats facing Israel. It would rely on a land-based sensing system and a land-based missile interception 
system. For Abrahamson, the Israeli project eventually would contribute to the technological development of SDI systems. This Israeli project was named Homa (the Hebrew acronym for hetz $v^{\prime} m a^{\prime}$ arekhet hatra'a, "Arrow and Warning System"), and its first program was the Arrow system, which was designed through a contract with Israel Aerospace Industries (IAI) financed by the United States. ${ }^{6}$ IAI's proposal was bold and innovative. As Brigadier General Uzi Eilam, then the director of MAFAT, remembers:

they [IAI] offered an eloquent and comprehensive presentation of a new high-powered intercepting missile with dreamlike maneuverability and an interception altitude of dozens of kilometres. ${ }^{7}$

The Arrow system was to include an antimissile interceptor relying on data provided by an early warning radar added to a command, control, communications, and intelligence center and a launch control center.

Meanwhile, the proliferation landscape in the Middle East was evolving. Having signed the Camp David Accords of 1978, Egypt progressively withdrew from the competition for ballistic arsenals in the region. The joint venture with Argentina and Iraq to build the Badr-2000 was disbanded in 1989. The new competitor in the 1980s was Saddam Hussein's Iraq. In 1 decade, the regime would become the first ballistic power in the region. In July 1990, the CIA wrote in a memo, "Iraq has the most aggressive and advanced ballistic missile development program in the Arab World." ${ }^{8}$ Like the Egyptians, the Iraqis had benefited from Soviet help in the 1970s and the 1980s to acquire Scuds. Iraqi engineers modified the Soviet model to develop the Al Hussein missile that would prove 
decisive in the war with Iran. Along with that missile, several projects were initiated to acquire long-range delivery systems, including one codenamed "Project Babylon" that intended to produce a system called "Supergun," a giant cannon with a planned range of several hundred kms. ${ }^{9}$ In addition, Saddam's Iraq possessed a wide array of tactical missiles (Frog-7, Ababil-50, Sajeel-60k, and Laith-90).

It is worth noting that, although Israel had quietly started cooperating with the United States in the missile defense field, the first wake-up call in Tel Aviv came with the so-called "war of the cities" between Iran and Iraq that took place between 1985 and 1988. During that period, both countries used missiles against the enemy's urban centers. Inside the Israeli Ministry of Defense (MOD), planners started looking at this conflict and its strategic meaning.

One of the key decisionmakers in the Israeli MOD during that period was David Ivri. A general from the Reserve, Ivri had been Chairman of the Board of Israel Aerospace Industries (IAI) when Israel-U.S. cooperation started. In 1986, he was appointed Director General of the MoD by Israel's then Minister of Defense, Yitzhak Rabin. Among other responsibilities, Ivri would be Israel's chief representative to the U.S.-Israel Strategic Dialogue. Ivri quickly realized the significance of the "war of the cities" and set up a task force to study it. Between February 29 and April 20, 1988, Iraq would launch 190 Al Hussein missiles on Iranian cities. Overall, Iraqi missiles killed more than 2,000 Iranians and injured 6,000. The campaign over Tehran caused the displacement of around 2.5 million Iranians. ${ }^{10}$ For Ivry and his task force, the conclusion was clear: it was Saddam Hussein's ballistic missile strategy that eventually made the difference and 
forced the Ayatollah Khomeini to concede the end of the war. ${ }^{11}$ What it meant for Israeli analysts was that Saddam Hussein was using Scud missiles to strike Tehran as new means of compellence. This is now corroborated by the release of Saddam Hussein's archives that allow us to have a detailed account of Saddam's understanding of the strategic value of ballistic missiles. In 1984, before the war of the cities started, the Iraqi leader was explaining to his Air Force officers:

Sometimes what you get out of a weapon is when you keep saying, 'I will bomb you' [and] it is actually better than bombing him. It is possible that when you bomb him the material effect will be 40 percent, but if you stick it up to his face the material and the spiritual effect will be 60 percent, so why hit him? Keep getting 60 percent. $^{12}$

For the analysts of the Israeli MoD, this meant that Saddam's calculus vis-à-vis Iran could easily be used against Israel in the future. A few years later, David Ivri would articulate his views in a speech delivered at the Begin Sadat Center:

the looming threat from proliferating ballistic missiles requires us to look at Israel's defense doctrine. Deterrence is no longer a sufficient policy, not when Israel's civilian population becomes exposed to long-range missile attacks. ${ }^{13}$

The words of Ivri were most likely those that he used to support the development of the Arrow system in the early-1990s.

The Iraqi missile threat got even more concrete for the Israelis 3 years later. On January 18, 1991, only 1 day after the start of Operation DESERT STORM, Sad- 
dam Hussein tried to regionalize the conflict by launching 42 Scud missiles on Tel Aviv, Haifa, and Dimona, Israel. The coalition forces led by the United States tried to detect the Iraqi mobile launchers but failed. The material and human damage inflicted by the Iraqi attacks was relatively low - one Israeli killed-but it generated such a climate of angst in the country that it caused 15 heart attacks. The psychological effect of the missile bombardment revealed an urgent need for reassessing the Israeli military posture. As a former official from the Israeli Ministry of Defense explained:

The Iraqi strikes dramatically challenged one of the intellectual foundations of the creation of Israel as the homeland of the Jews that would protect them against all persecutions and attacks: the ballistic proliferation jeopardizes this belief. ${ }^{14}$

But even then, both the military establishment and the politicians feared that this resort to defensive means was misleading. The fact that most of the costs were covered by the Americans mitigated the risk of bureaucratic resistance. Starting in Fiscal Year 1990, the United States contributed up to $\$ 52,000$ million to the program. Several other bilateral agreements were signed: a Memorandum of Agreement in 1989 specified U.S. aid to the designing of an Israeli computer facility for the Arrow Program; another one in 1991 secured the U.S. contribution to the second generation Arrow capability. The first test of the Arrow missile was conducted in 1990.

As the Israelis and the Americans were cooperating on the Arrow missile, the Iraqi threat was slowly fading away. With the international embargo ensuing from the Gulf war, the Iraqi arsenal declined. But even with Saddam Hussein subdued, missile prolif- 
eration in the Middle East did not come to a halt, it only changed the distribution of main actors, with Syria and Iran being the rising challengers. Leaders in Damascus and Teheran would learn the lessons from Saddam's use of ballistic missiles to acquire their own capabilities.

During the 1970s, acknowledging his inability to reach strategic parity with Israel in the conventional domain, Syrian leader Hafez al Assad began his search for rockets and missiles. His first support came from the USSR with the purchase of the R-70, a short-range ballistic missile (SRBM) delivered in 1973 shortly before the war with Israel. Like the Egyptians, the Syrians also used their missiles during that conflict, but the technical limitations of the R-70 (poor range and accuracy) made it ineffective. A year later, the Soviet Union provided Assad with Scud-B missiles. However, with the collapse of the Soviet Union in the 1990s, Syria turned to other providers such as the North Koreans and the Iranians. Specifically, Pyongyang delivered Scud-B and Scud-C missiles to Damascus in the early-1990s. In 2008, a State Department report to Congress assessed:

Over the past decade, Syria has focused on enhancing the capabilities of this [SRBM] force while also achieving self-sufficiency in indigenous missile production. With North Korean assistance, Syria has made progress toward domestic production of a Scud missile variant. ${ }^{15}$

Furthermore, in 2013, Defense Intelligence Agency Director Michael Flynn stated to the Senate Armed Services Committee that "Damascus relies on foreign help, mainly from Iran, to advance its solid-propellant rocket and missile development and production 
capability." ${ }^{16}$ Despite efforts by both Hafez and his son, Bashar, Syrian indigenous capabilities remain limited, and its missile arsenal primarily relies on its Iranian and North Korean partners. Before civil war erupted in 2011, Israeli sources estimated that Syria had more than 50,000 rockets and missiles, including around 200 Scud-B and 80 Scud C/D whose range could be up to $700-\mathrm{km} .{ }^{17}$ Due to the conflict and speculation over the relocation of the regime's weapons, current capabilities are hard to assess.

With regards to Iran, in the 1980s, its leadership launched its ballistic enterprise as a direct result of the 8-year war with Iraq. The 1985-88 war of the cities engendered such national trauma that Tehran wanted to bridge the gap with any of its future foes. The Iranian ballistic program benefited from the same proliferation network: North Korea, China, and Russia. If Iraq was the leading ballistic power of the Middle East in 1991, Iran was now replacing it.

Opacity surrounds the state of Iran's current arsenal. It is said to include hundreds of short-range missiles such as the Shahab-1 and Shahab-2. ${ }^{18}$ There is contradicting information regarding another SRBM, the Quiam, which allegedly was only tested once in August 2010. Sources assess "the Quiam to be based on the Shahab-2, with a range between 500 and 1,000 kilometres." 19 The Fateh-110 is another SRBM whose development started in the mid-1990s. Although Iranians claimed its range was nearly $300-\mathrm{km}$, independent experts argue that it is more likely to be closer to 200-250-km. ${ }^{20}$ Iranian medium-range ballistic missiles (MRBMs) include the Ghadr-1, a variant of the Shahab-3. The Sejil, a solid-fueled ground-mobile ballistic missile, was tested successfully in November 2008. Able to reach a target up to $2,200-\mathrm{km}$, the Sejil has a 
payload capacity that could accommodate a nuclear warhead. Finally, Iran has also developed numerous rockets such as the Fajr, the Zelzal, and the Fateh-110. ${ }^{21}$

Because of this evolving threat environment, Israeli efforts in the missile defense field in the 1990s focused on addressing the challenge posed by the rising Syrian and Iranian arsenals. In July 1995, a first test of the Arrow-2, an operational version of the Arrow-1, was declared successful. Arrow-2 was co-produced by IAI and Boeing. The interceptor aimed at destroying an incoming target with a fragmentation warhead. It would address the threat of SRBMs and MRBMs. Over the following 3 years, various tests were conducted, and, in light of the evolution of the Middle Eastern security environment, Israeli planners started considering that an increase in the funding of Arrow was needed. After consultations in Washington, U.S. Secretary of Defense William Cohen announced in March 1998 that the U.S. Government would expand the project and provide funds for a third Arrow battery. "Israel has determined, in light of the growing missile proliferation in the region, that it would need three batteries to protect much of its population," Cohen said. ${ }^{22}$ In May 1998, Israeli Minister of Defense Yitzhak Moredachai approved a 10-year-plan to continue development and production of the joint U.S.-Israeli Arrow-2 system. ${ }^{23}$

The initial operational capability of the Arrow-2 was achieved in December 2000. Batteries were then deployed at Palmachim and Ein Shemer, two cities flanking the Tel Aviv area. In August 2008, the U.S. and Israeli governments decided to move forward on the Arrow program by initiating the development of a new component, the Arrow-3. A two-stage interceptor, Arrow-3 was designed to destroy an incoming tar- 
get with an exo-atmospheric kill vehicle. The explicit ambition of this additional missile is to intercept long range ballistic missiles (LRBMs) carrying weapons of mass destruction. This third version of Arrow experienced a successful test flight in January 2014.

Under the framework of U.S.-Israel cooperation, various other technical studies were conducted during the 1990s. One initiative worth mentioning was Project Nautilus, designed to develop a tactical high energy laser to intercept rockets. On July 18, 1996, the United States and Israel signed an agreement to produce the prototype weapon jointly. It was mainly funded by the U.S. Army Space and Missile Defense Command (80 percent of costs). But when the development was completed, decisionmakers assessed the system negatively, and the Pentagon decided to stop allocating resources to the program in 2006.

Soon, opponents to Arrow, and more broadly to Israel's missile defense enterprise, raised their voices. Among them, Reuven Pedatzur, a security analyst for the leading newspaper Haaretz, wrote a muchdiscussed report in 1993 for the Jaffee Center for Strategic Studies. ${ }^{24}$ In his study, Pedatzur pointed out that the cheap cost of rockets and missiles would render the expensive Arrow program not only operationally irrelevant but dangerous for Israel's military budgeting process. Added to the cost ineffectiveness of Arrow, Pedatzur underlined the technical uncertainties of missile defense. In particular, he feared the missile proliferation trends in the region would go much faster than the development of Israel's program. In 2000, Pedatzur wrote:

According to Israeli military intelligence estimates, by mid-decade [2005], the Iranians, and perhaps the 
Iraqis as well, will have nuclear-tipped ballistic missiles in their arsenal. And when that happens, the Arrow defense system will be totally useless, because its developers are not prepared to guarantee that the Arrow can intercept every missile fired at us. Which is very bad news, indeed, because it is obvious to everyone that Israel cannot afford to pay the price of even one nuclear missile hitting a target anywhere in this country. ${ }^{25}$

His arguments would soon become the primary criticisms used against the proponents of Arrow. Because the technological unknowns also meant financial unknowns, the U.S. contribution to the program became critical. It can be said that without U.S. financial support, Arrow would probably not have been developed by the Israelis. In his memoirs, Brigadier General Uzi Eilam, former head of Israel's procurement agency MAFAT, confirms this:

Opposition to the missile defense program within the IDF [Israeli Defense Forces] stemmed from concerns that at a certain point it would start requiring large allocations from the defense budget. As long as the funding for development came almost exclusively from the budget of the US Strategic Defense Initiative Organization, the army's resistance was not influential. ${ }^{26}$

Additionally, in 2008, the United States deployed an X-Band radar system in the Negev that completes Israel's own early warning system. ${ }^{27}$ It also gives Israel the possibility to gain access to the U.S. Department of Defense (DoD) global satellite system. Though the Americans keep complete control over the system, it is hard to conceive a scenario in which Washington would deny the transmission of information to 
Israel related to the launching of a missile targeting that state.

Starting in 2001, the United States and Israel have also been conducting operational exercises such as Juniper Cobra or Austere Challenge directly relevant to these matters. The aim of Juniper Cobra, held once every 2 years, is to enhance the joint ability of both U.S. and Israeli military forces to respond to missile attacks. The scenario used for the 2009 edition was a missile attack by Iran. ${ }^{28}$ Austere Challenge is an annual air-defense exercise that involves more than 3,500 U.S. personnel and 1,000 Israeli troops. It also aims at improving the interoperability between the IDF and U.S. European Command, using equipment such as Patriot air defense batteries and the Aegis ballistic missile defense ship.

The U.S.-Israeli cooperation on the Arrow was in many ways exceptional: borne out of the ideas of Israeli engineers, the program was entirely funded by the SDIO, at least in the initial years, for a customer that was facing internal resistance. This fact is counterintuitive with the contemporary narrative that depicts Israel's infatuation with missile defense, but the enterprise initially went against the country's strategic culture. (For U.S. contributions to the Arrow Program, see Table 1.) Mentalities evolved slowly, and by the mid-2000s, the domestic context would be much different when Israel started its own development of another program: Iron Dome. 


\begin{tabular}{|c|c|c|c|}
\hline \multicolumn{4}{|l|}{ \$ in millions } \\
\hline Fiscal Year & Total & Fiscal Year & Total \\
\hline 1990 & 52,000 & 2,004 & 144,803 \\
\hline 1991 & 42,000 & 2,005 & 155,290 \\
\hline 1992 & 54,400 & 2,006 & 122,866 \\
\hline 1993 & 57,776 & 2,007 & 117,494 \\
\hline 1994 & 56,424 & 2,008 & 118,572 \\
\hline 1995 & 47,400 & 2,009 & 104,342 \\
\hline 1996 & 59,352 & 2,010 & $1,222,342$ \\
\hline 1997 & 35,000 & 2,011 & 125,393 \\
\hline 1998 & 98,874 & 2,012 & 125,175 \\
\hline 1999 & 46,924 & 2,013 & 115,500 \\
\hline 2000 & 81,650 & 3,014 & 11,9070 \\
\hline 2001 & 95,214 & & \\
\hline 2002 & 131,700 & & \\
\hline 2003 & 135,749 & Total & $2,365,31$ \\
\hline
\end{tabular}

Table 1. U.S. Contributions to the Arrow Programs (Arrow, Arrow II, Arrow III). ${ }^{29}$

\section{UNDER THE IRON DOME}

The first phase of Israel's missile defense enterprise was driven by the growth of ballistic arsenals by Arab neighbors and Iran. The second phase was to be characterized by the rise of a new threat, one coming not from sophisticated delivery systems but from rudimentary rockets. These weapons were not held by Middle Eastern States but by nonstate actors. Specifically, Israeli planners have faced over the last 2 decades a new challenge with organizations like Hezbollah and Hamas being able rapidly to acquire rocket systems that for a long time were the monopoly of states. Such a phenomenon demanded a second bottom-up 
review of the Israeli military posture. Because the Party of God and Palestinian factions had long been using terrorist techniques such as suicide bombing, IDF troops were trained to react through counterterrorism or counterinsurgency measures. However the advent of rocket arsenals and their strategic use by Israel's enemies made this military answer ill-suited. This triggered the design and development of a new defense system that would unexpectedly become the most iconic system of Israeli military power: the Iron Dome. Along with Iron Dome, a third missile defense system, David's Sling, was designed.

Historically, the first nonstate actor to constitute a significant military threat to Israel was and remains Hezbollah. The movement was created during Lebanon's civil war by Shia militiamen formerly affiliated with Amal and benefited from the support of both Iran and Syria. Although Hezbollah was ideologically a by-product of the Iranian Islamic revolution, it also arose from Israel's military occupation of south Lebanon, a region primarily populated by Shias. In its first years, Hezbollah used classic terrorist techniques against the IDF such as suicide bombing that targeted the IDF convoys in the south of the country. But progressively its leadership turned to other options.

On February 16, 1992, Israeli helicopters fired missiles at the motorcade of Secretary General of Hezbollah Abbas al Musawi, killing him and six other persons. Musawi was immediately replaced by the charismatic and then young Hassan Nasrallah. One of Nasrallah's first decisions was to order the firing of Katyusha rockets at Israel's northern cities in retaliation against the assassination of Abbas Musawi. This was the first time Hezbollah launched rockets on Israel's soil. 
Katyushas rockets had been first built by the Soviet Union in World War II. They include the BM-13 truckmounted rocket launcher, light BM-8, and heavy BM31 . They have a maximum range of $20-\mathrm{km}$ and carry a 30 kilogram warhead. The poor technical features of Katyushas make them rather ineffective: before the war of 2006, it was estimated that Hezbollah would need "about 73 rockets to kill one Israeli." ${ }^{30}$ Nevertheless, Hassan Nasrallah soon saw the benefit of this arsenal and envisioned it as a potential deterrent. Although Palestinian Fatah had used Katyushas as early as 1968, no other organization than Hezbollah made it a strategic weapon.

On February 27, 1992, only 10 days after the assassination of Musawi, Nasrallah gave a revealing interview to the Lebanese newspaper, Al Safir. Asked about the logic of launching Katyushas, he replied:

We have to work ... toward creating a situation in which the enemy is subject to our conditions. We should tell him: 'If you attack us, we will use our Katyushas; if you do not attack us, we will not use our Katyushas'. ${ }^{31}$

In many ways, Hezbollah's leadership was applying to the use of rockets the same strategic rationale as did Saddam Hussein: they were not only a means to circumvent the military imbalance with Israel, but also a concrete tool to coerce the Hebrew State.

During the 1990s, Hezbollah's military structure became increasingly sophisticated, with one combat unit specifically trained with rocket launchers. In addition to clashes with the IDF in the south of Lebanon, the Party of God would now use its rockets to inflict damage to civilian populations in the north of Israel. In June 1993, rocket attacks on Kiryat Shemona trig- 
gered Israel's Operation ACCOUNTABILITY. The campaign proved inconclusive. In the spring of 1996, a new cycle of escalation started with the IDF shelling the Lebanese village of Yatar and Hezbollah responding by launching rockets on Israeli cities. This led to the Operation GRAPES OF WRATH that also ended without a clear victory. In 2000, following the withdrawal of the Israeli military from the south of Lebanon, Hezbollah started a major build-up in the area. Using concealment techniques, its fighters deployed thousands of rockets along the border with Israel, sometimes hiding them in private houses. Additionally, the organization had acquired new, more sophisticated systems such as the Iranian Fajr-3 (42$\mathrm{km}$ range), the Zalzel-1 and 2 that are able to reach targets up to $125-\mathrm{km}$ and $210-\mathrm{km}$, respectively. In 2005, as France and the United States were pressuring the Lebanese government to disarm Hezbollah, Nasrallah stated:

I say, with the commanders' permission, that we have more than 12000 rockets. The real value and power of these rockets comes from the fact that they are in our hands, and that the Zionists know neither their number nor where they are deployed. They are fighting a hidden and an unseen enemy that could surprise them on any given day with this large number of rockets. ${ }^{32}$

A year later, the strategic significance of Hezbollah's arsenal was no longer ignored. On July 12, 2006, and after 6 years of limited skirmishes, Hezbollah forces launched a salvo of rockets on the Galilea and ambushed an Israeli patrol driving along the IsraelLebanon border. For the IDF, the result of this fierce fight was dramatic: a Merkava tank was destroyed, eight soldiers were killed, and two others were 
abducted (Ehud Goldwasser and Eldad Regev.) In the late afternoon of the same day, Israeli Prime Minister Ehud Olmert gave his approval to IDF Chief of Staff Dan Halutz to set in motion a counterattack to "turn back the clock in Lebanon by 20 years." ${ }^{33}$ While Israel's naval forces enacted a naval blockade of Lebanese shores, the Israeli Air Force (IAF) targeted Hezbollah positions in Southern Lebanon, its headquarters in the Dahya neighborhood of Beirut, as well as roads, bridges, and the Beirut Airport. By its scale, this was "the first sustained modern air campaign conducted by a country other than the United States." ${ }^{\prime 4}$ During the campaign's first 7 days, some 2,000 jet fighter and attack helicopter sorties were conducted by the IAF, with often 40 to 70 aircraft operating concurrently in the airspace above southern Lebanon. ${ }^{35}$ In spite of the intensity of Israel's strikes, Hezbollah retaliated with rocket fire against Haifa on July 13, 16, and 17: the first time that the city came under attack since the launching of Scud missiles by Saddam Hussein during the 1991 Gulf War. ${ }^{36}$ Hezbollah's rockets also reached Tiberias on July 15 and 17, and Afula on July 17.

For Israeli strategists, the lessons were twofold: the Party of God had sufficient means to sustain a long campaign, and its arsenal was able to reach cities deep inside the Israeli territory. The hard conclusion was that intelligence agencies clearly failed to estimate Hezbollah's military power. ${ }^{37}$ In particular, Hezbollah's use of Chinese-made, Iranian-upgraded C-802 radar-guided missiles against an Israeli missile boat patrolling off the Lebanese coast took the planners in Tel Aviv by surprise. The result was that Israel experienced more casualties on its soil because of Hezbollah than because of any previous efforts from Arab conventional forces. Colonel Gabriel Siboni from the 
Tel Aviv-based Institute for National Security Studies portrays this shift as the new strategic concept of Israel's enemies:

The size of Israel and the fact that it has no strategic depth made Israel's enemies assume that high trajectory fire aimed at the Israeli home front in large quantities and with a minimum of variables would allow them to achieve their goal. ${ }^{38}$

Likewise, former Israeli National Security Advisor Giora Eiland emphasizes the fact that:

the number of long and medium range rockets within the overall arsenal skyrocketed, which will enable Hezbollah to continue firing even if Israel occupies the entire area between the border and the Litani River. ${ }^{39}$

If the Iran-Iraq "war of cities" had been the first wake-up call that urged the development of the Arrow program, the 2006 war against Hezbollah clearly constituted the second wake-up call that would demand a response to the challenge posed by rockets and short range missiles. Nine years after the conflict, the number of rockets and missiles under the control of Hezbollah is difficult to know. In September 2008, Israeli Minister of Defense Barak estimated that Hezbollah had 40,000 rockets. One year later, President Shimon Peres suggested that the figure was close to $80,000 .{ }^{40}$ IDF officials interviewed for our research stated that the number was about 42,000 rockets, plus 4,000 short to mid-range missiles. ${ }^{41}$

The quality of the arsenal dramatically improved as Hezbollah acquired rockets using guidance systems and with extended range. During that same period, the arms race crossed a new threshold as Hezbollah 
started acquiring ballistic missiles. It is believed that the Party acquired through Syria M-600 SRBMs, a variant of the Fateh-110, which can carry a 1,100-pound warhead and has a range of $210-\mathrm{km}^{.2}$ According to weapon engineers, the inertial guidance system of the M600 enables the missile to strike within 500 yards of a target at maximum range.

Furthermore, Hezbollah's rockets strategy was quickly emulated by other organizations in the region, and first by Hamas. The first use of a Qassam rocket by Palestinian groups in Gaza can be traced back to 2001. When Prime Minister Ariel Sharon decided to withdraw the IDF from the Gaza Strip in 2005, Hamas leaders claimed victory. Hamas leader and disputed Prime Minister Ismail Haniyeh declared "Sharon cannot evade the truth. The Qassam [rocket] is what forced the enemy out." 43

The Qassam rockets are home-made projectiles that easily can be made using material available in the public domain. The cost per unit amounts to less than $\$ 1,000$. Due to their small size and relative light weight, they can be launched without the use of stationary launchers. They are what Uzin Rubin calls "man portable rockets." ${ }^{44}$ According to Hamas's sources, four models have been developed over the last years. The Qassam I ranges 3-km and consequently can only reach urban places like Sderot, the western Negev city. The Qassam II has a range of up to 7-km, which "only" enables it to target the city of Sderot in southern Israel and surrounding areas. However, with a maximum range of $10-\mathrm{km}$, the Qassam III puts Ashkelon in its reach. The Qassam IV, still in its trial stages (but which has already hit Ashkelon), would have a range of $15-\mathrm{km}$. 
In his book, A High Price, Daniel Byman provides an insightful account of rocket attacks from Gaza during the previous decade. It shows how Palestinian factions followed Hezbollah's pattern and increasingly relied on rockets as means to attack Israel. Main cities targeted were Sderot, Beersheba, and Ashkelon. (See Table 2.)

\begin{tabular}{|c|c|c|c|}
\hline Year & $\begin{array}{c}\text { Number of } \\
\text { Qassam Rockets } \\
\text { Launched }\end{array}$ & $\begin{array}{c}\text { Number of } \\
\text { Mortar Shells }\end{array}$ & Israeli Fatalities \\
\hline 2000 & 0 & 0 & 0 \\
\hline 2001 & 0 & 510 & 1 \\
\hline 2002 & 17 & 455 & 0 \\
\hline 2003 & 123 & 514 & 0 \\
\hline 2004 & 276 & 882 & 9 \\
\hline 2005 & 2,86 & 574 & 6 \\
\hline 2006 & 1,247 & 28 & 2 \\
\hline 2007 & 938 & 663 & 2 \\
\hline 2008 & 1,270 & 912 & $\begin{array}{c}8 \text { (4 during Operation } \\
\text { CAST LEAD) }\end{array}$ \\
\hline 2009 & 4,004 & 197 & $\begin{array}{c}5 \text { (all soldiers killed } \\
\text { from mortar shells } \\
\text { during Operation } \\
\text { CAST LEAD) }\end{array}$ \\
\hline
\end{tabular}

\section{Table 2. Rocket and Mortar Attacks Fired at Israel} from Gaza. ${ }^{45}$

But in addition to these indigenous capabilities, Hamas also acquired rockets from its state sponsors, namely Iran. In November 2012, for the first time, the Palestinian group used the Fajr-5 rocket. With a range of $75-\mathrm{km}$, the Fajr-5 is a major leap forward vis-à-vis the Qassams. Israeli experts assume the arse- 
nal is channeled to the Palestinians through the Sinai Peninsula and then the tunnels to Gaza. IDF officials usually argue that the smuggling of rockets through the Gaza-Egypt tunnels increased tremendously after the 2005 withdrawal. First, Hamas's hold on the Palestinian side favored the construction of new tunnels; and, second, the collapse of Hosni Mubarak's regime in 2011 and the subsequent instability in Egypt let the smugglers enjoy a security vacuum. Overall, the Israeli military estimates that Hamas has approximately 6,000 rockets in the Gaza Strip. Out of these 6,000, 4,000 would be short range, 1,600 mid-range, and 100 long-range rockets.

Along with Hamas, other groups with significant arsenals include the Islamic Jihad, which would have about 2,400 short range rockets, 800 Grad mid-range rockets, and 100 mid-to-long range rockets. ${ }^{46}$ But beyond the Islamic Jihad, there are numerous extremist fringes that hold some rockets and do not hesitate to launch them against Israel. Over the last decade, jihadi groups such as the Majlis Shura Al Mujahedeen, Jaysh al Umma, Tawhid Wa'al Jihad, and others have proliferated in Gaza. Estimates of their numbers and strength vary widely: in a publication from the U.S. Military Academy, the Israeli expert Benedetta Berti wrote that "the network consists of approximately 4,000-5,000 members, although its alleged followers could be as many as 50,000 people." ${ }^{47}$ Their arsenals are much smaller than those of Hamas or of Islamic Jihad. According to the Jewish Policy Center, the Popular Resistance Committee has rockets that, at best, can reach targets within a range of 9-km. The Popular Front for the Liberation of Palestine could launch Sumud rockets with a maximum range of $7-\mathrm{km}^{48}{ }^{48}$ Furthermore, the relationship between these factions and Hamas' 
military wing is difficult to evaluate, as these groups often recruit dissidents of Hamas disappointed by the diplomatic pragmatism of its leadership.

The same way the development of Arrow followed the spread of ballistic missiles in Israel's vicinity, the proliferation of rockets in Gaza and Lebanon triggered the designing of two new defense systems: Iron Dome and David's Sling. A major difference from Arrow was that this time, Israel did not wait for a cooperation agreement with the United States, it initiated both programs on its own.

By all standards, the pace of Iron Dome's development was impressive. The program was officially launched by Rafael Advanced Defense Systems in February 2007, and it took less than 5 years to see the first battery on the field. With Iron Dome, Israeli engineers aimed to build an air defense system able to intercept short-range rockets (between $4-\mathrm{km}$ and 70$\mathrm{km})$. One battery theoretically could protect an area of up 150 square $\mathrm{km} .{ }^{49}$ The system is based on three core components: a detection and tracking radar, a missile firing unit, and a battle management control. An Iron Dome battery includes an ELM-2084 S-Band phasedarray radar, fire-control center, and three launchers capable of carrying 20 Tamir interceptors. The Tamir is three meters long and uses a proximity-fused explosive warhead to destroy rockets in midair. Each battery is said to cost about $\$ 50$ million, with one interceptor amounting to $\$ 50,000$. $^{50}$

Following the development of Iron Dome, in 2009, the IAF established a new battalion dedicated to operating the system. This unit is part of the Air Force's air defense division and is also the one responsible for formulating a doctrine for operation. The first Iron Dome batteries were deployed in October 2011 in the 
Southern cities of Ashdod, Ashkelon, and Beer Sheba, in other words, the threat driving Iron Dome was the one coming from Gaza. Each Iron Dome was said to cost about $\$ 50$ million. An additional sixth battery was fielded in September 2013 in reaction to the troubles at the border with Syria.

The other system, called David's Sling (or Magic Wand), is designed to counter medium-range rockets (e.g., Iran's Fatah 110) and cruise missiles that could be fired from $40-\mathrm{km}$ to $300-\mathrm{km}$. The project was initiated before the Israel-Hezbollah war, but development started in late-2006 with a joint venture by the Israeli company, Rafael, and the American company, Raytheon. Rafael developed the interceptor while Raytheon worked on the command and control devices, the launcher, and the radar. David's Sling can be understood as the intermediate system between Iron Dome, which addresses the long-range projectiles, and Arrow, which intercepts ballistic missiles. In November 2007 , the U.S. Congress approved the provision of $\$ 155$ million to Israel for the development of David's Sling. As of this writing, its development is still ongoing and has faced challenges. Though the system initially was expected to enter into service in 2013, its schedule has been modified several times. It is now said to become operational around 2016. Field tests have been so far successful, but budget shortfalls threaten to jeopardize its delivery. According to an IDF official interviewed by Reuters, "We don't have the money here to pay for the infrastructure." ${ }^{11}$ Whereas David's Sling is barely known outside of the world of missile defense experts, Iron Dome became widely popular in the spring of 2012, with its use against rockets fired from Gaza.

On March 9, 2012, Israeli forces eliminated Zuhar el Keisey, commander of the Palestinian Resistance 
Committee. No more than 3 hours later, the Islamic Jihad responded by firing rockets on Israel. By the evening of that day, cities like Beersheba and Ashdod had been targeted. About 70 rockets had been used in the first 12 hours of the fighting. ${ }^{52}$ In the following days of the escalating confrontation, the IAF used Iron Dome batteries to counter the launching of over 160 rockets on urban centers in South Israel. Eventually, the success rate of Iron Dome during the campaign was estimated to reach 86 percent. ${ }^{53}$ The two following campaigns - Operation PILLAR OF DEFENSE in November 2012 and Operation PROTECTIVE EDGE in July 2014 - confirmed the new foreground role conferred on Iron Dome. In the aftermath of Operation PILLAR OF DEFENSE, Yiftah Shapir from Israel's Institute for National Security Studies named Iron Dome "the queen of battle." It was also reported that a "large number of recruits to combat units ... had expressed a desire to be assigned to Iron Dome." ${ }^{54}$ This signaled a new step in the evolution of Israel's military mindset toward missile defense.

Such success also had financial implications. Facing budgetary constraints, Israeli defense planners turned to the Americans who, until then, had been primarily co-sponsoring the Arrow system. For the year 2011, DoD spent $\$ 205$ million to support the development of Iron Dome, which equals 87 percent of U.S. financial aid to the other missile defense programs (Arrow II and III and David's Sling). ${ }^{55}$ In 2013, the United States authorized \$211 million in support. In the spring of 2014, this amount dramatically increased as the Missile Defense Agency promised a transfer of \$429 million in funding, more than double the amount from 3 years before..$^{56}$ 
In fact, a close look at the allocation of U.S. financial aid to Israel allows us to note that of $\$ 235$ million dedicated to Israel's missile defense systems (excluding Iron Dome), Arrow systems only represent around 50 percent. These figures suggest that a major part of Israeli and American resources go to the funding of systems tackling the short-range threats; those coming from Palestinian militias in the Gaza Strip and from Hezbollah in Lebanon, not from Iran or Syria. Overall, this steady increase in the level of U.S. support to the Israeli systems evidences the new centrality of missile defense in the U.S.-Israeli military cooperation. But it may also reveal a paradox with Israel's missile defense: its most expensive system is the one countering the cheapest threats. This calls in the next section for a detailed discussion of the strategic lessons of this missile defense enterprise.

\section{THE STRATEGIC MEANING OF ISRAEL'S EXPERIENCE}

With the worldwide attention gained by Iron Dome, missile defense has now become a central topic of the strategic debate in and on Israel. The apparent successes of the system in the past campaigns triggered swift passion, if not infatuation, for the whole enterprise. In a dramatic tone, observers like Taylor Dinerman from the Gatestone Institute, started writing:

Between the fall of the Jewish Commonwealth to the Romans in the first century A.D. and the founding of Israel in 1948, Jews were remarkably easy to kill. Not anymore. Today, thanks to an innovative missiledefense system called Iron Dome (in Hebrew Kipat Barzel), it's harder than ever. ${ }^{57}$ 
Such assertions reflect the current mindset, not only among the pundits but also among Israeli and American politicians.

There is a logic to that passion for missile defense, and we can mention three core arguments. First, for the decisionmakers in Jerusalem and Tel Aviv, the effectiveness of missile defense systems is a precious justification for the expenditures that have been dedicated over the last 3 decades to Arrow, Iron Dome, and David's Sling. It plays a key role in budget battles on the domestic front in an era of austerity, which raises the level of scrutinization over costly military programs. It also helps make the case for increased U.S. financial aid allocated to these programs. The second reason is ideological: politicians expect Israel's missile defense to sanctuarize the territory in order to reaffirm the principle of the Jewish State as the homeland able to defend the Jews against any persecution. Missile defense then becomes a precious tool for the government to reassure citizens regarding their safety and mitigates the psychological effects of missile warfare. Last, there is a strategic rationale behind Iron Dome that appeals to decisionmakers: effective missile defense systems provide them with new options against an attack. It can negate the ability of the attacker to harm the Israeli population and, as a result, allows the government to avoid launching an unnecessary ground operation to retaliate against its enemies. This last argument was salient in the aftermath of the 2012 Operation PILLAR OF DEFENSE. ${ }^{58}$ However, this missile defense fad is troubling because it engenders various misunderstandings. We address four of them. 


\section{Misunderstanding \#1.}

The first misunderstanding relates to the technical capacity of these systems. Believing in the sanctuarization of Israel's territory, thanks to Iron Dome or Arrow, is deluding. First, it overestimates the current and future geographical coverage of these systems. As in many other countries, Israeli politicians ambiguously imply that the systems aim at defending the homeland as a whole, when in reality the existing systems protect first and foremost critical infrastructures and military bases. In 2010, General Gadi Eisenkot, the then head of the Northern Command, stated:

the residents of Israel shouldn't be under the illusion that someone will open an umbrella over their heads. The systems are designed to protect military bases, even if this means that citizens suffer discomfort during the first days of battle. ${ }^{59}$

The declaration caused troubles within the political class, in particular among the elected representatives from the Southern cities that faced most of the rocket threat from Gaza. The semantics of "theater" to "territorial" missile defense matter. This might seem like a minor change, but its operational implications are huge. Even according to the proponents of Iron Dome, a comprehensive coverage of the territory would require more than a dozen batteries whose affordability remains yet uncertain.

The other issue at the technical level relates to the exact effectiveness of the systems. If Arrow has not been tested in a real confrontation, Iron Dome has. Official figures on the system's performances are frequently impressive. During Operation PILLAR OF DEFENSE in November 2012, Iron Dome is said to 
have achieved a success rate of 85 percent. Of the 1,506 rockets fired at Israel, only 58 fell in urban areas. The results during Operation PROTECTIVE EDGE in July 2014 were even higher. According to military sources, the system hit over 600 rockets fired, a 90 percent success rate. ${ }^{60}$ Understandably, these spectacular results led to political euphoria.

But there are some caveats that need to be considered. Several technical experts have expressed caution with the figures released by the IDF. In particular, Theodore Postol, a physicist at the Massachussets Institute of Technology, triggered a fierce controversy in the midst of Operation PROTECTIVE EDGE through several pieces he wrote in which he argued that the performance of Iron Dome was much lower than the official data suggest. Using photographs of Iron Dome intercept attempts, Postol affirms:

My best estimate is that fewer than 20 percent of the engagements I was able to get data on were actually front-on, and I have no information about the actual miss distances or whether the engagement-attempt geometries were close to antiparallel. Thus the statement that the intercept performance of Iron Dome appears to be probably 5 percent or less. ${ }^{61}$

For Postol, the limited number of Israeli casualties from rocket attacks is due less to the performance of Iron Dome than to both the small size of the rockets fired and the effective early warning plan that allowed civilians to find shelters. Because Postol's assessment has been widely quoted in international media, it has logically caused a major controversy among the experts. The first criticism addressed to Postol concerned his empirical evidence, as his analysis is based on "grainy YouTube downloads of Iron Dome 
interceptions." ${ }^{62}$ Uzi Rubin, one of the former engineers responsible for the Arrow program at the MAFAT, overrules Postol's conclusion:

Postol theorizes that it is Israel's civil defense system that does the work - that people, warned in time by sirens, take cover and are saved. Yet this does not explain why so few rocket strikes are registered in the large population centers that Iron Dome is designed to protect. Of the hundreds of rockets fired at the city of Ashdod to date, for example, only 12 hit residential areas. Are Hamas rockets that inaccurate? Why, after 60 or so heavier rockets have been fired at Tel Aviv, has not one impact been registered to date within city limits, save for the debris of visibly intercepted ones? ${ }^{63}$

Such controversy is nothing new when it comes to missile defense, as it reminds us of the similar way $\mathrm{Pa}$ triot batteries had been considered in the aftermath of the 1991 Gulf War. Initial reports suggested that PAC2 had achieved a 70 percent success rate, but later studies argued that the rate was closer to 10 percent. ${ }^{64}$ It is worth mentioning that Postol was already among those who rectified these figures. This dispute reflects uncertainties that should at least call for caution when looking at Israel's missile defense systems.

Overall, it is worth noting that the most conclusive results of Israeli systems have so far been achieved in the lowest tier. Iron Dome, which is mistakenly seen as the central, if not the only, node of Israeli missile defense architecture, aims at intercepting rudimentary rockets with a $4-\mathrm{km}$ to $70-\mathrm{km}$ range. In contrast, despite several tests, there are still doubts about the effectiveness of mid- and long-tier systems such as the Arrow or David's Sling. 


\section{Misunderstanding \#2.}

The second major misunderstanding or misread of Israel's missile defense apparatus relates to its deterrent effect. During the Cold War, missile defense systems were depicted as factors of destabilization in the balance of terror established through the nuclear stand-off between the United States and the USSR. It was believed in Western countries that only deterrence by punishment - the threat of either conventional or nuclear retaliation - would prevent proliferation and a widespread arms race. That was the basis of the Anti-Ballistic Missile Treaty of 1972. But in the case of Israel and the Middle East, this argument never really percolated.

Israel's missile defense enterprise was driven by the proliferation of ballistic missiles and rockets in its vicinity and the concomitant absence of a regional security system that would have regulated an arms control regime. But does it mean that Iron Dome, Arrow, and David's Sling constitute means of deterrence or denial that could put a halt to the proliferation trends in the region? Open sources on the arsenals deployed and developed in the region tend to negate this assumption. According to United Nations (UN) reports, Iran steadily pursues the development of its ballistic missiles. ${ }^{65}$ Lebanese Hezbollah not only rearmed after the 2006 war, but its lethal means got better. In recent years, it started acquiring ballistic missiles, and it is believed that the Party acquired through Syria M600 SRBMs, a variant of the Fateh-110, which can carry a 1,100-pound warhead and has a range of $210-\mathrm{km} .{ }^{66}$ With regards to Hamas in the Gaza Strip, Operation PROTECTIVE EDGE in the summer of 2014 revealed the capacity of the Palestinian organization to contin- 
ue firing rockets on Israel, even after almost 2 months of daily airstrikes. This calls at least for a sober assessment on the deterrent virtues of missile defense. This might be explained by the fact that the ratio between the cost of an Iron Dome battery and a Qassam rocket is such that it does not dissuade Palestinian organizations. This issue had been perfectly stressed by Bernard Brodie in his classic Strategy in the Missile Age:

We must say ... that in considering active defences, a realistic analysis does not first assume an offense and design a defense to counter it. In actuality the order is reversed. A defense is built, and the offense seeks to exploit its weak spots. And the history of the race thus far suggests that there is always a hole, an Achilles' heel. ${ }^{67}$

If one can argue that Arrow, in the long run, may be able to deter by denial neighboring countries that would be tempted to launch a missile on Tel Aviv or Jerusalem, nonstate actors like Hamas or the Islamic Jihad seem not to obey to these rules of deterrence. This relates to one particular issue faced by Israeli planners: the heterogeneity of threats. For countries like the United States and its NATO allies, the missile defense enterprise is driven by a clear scenario of intercontinental missiles coming from a State like Iran, whereas the Israeli enterprise is driven by several very distinct scenarios in terms of projectiles (rockets and short-, mid-, and long-range missiles) and in terms of enemies (state and nonstate entities). That situation engenders several challenges to the establishment of a deterrence system: can this system apply deterrence tailored to each of its threats? Can nonstate actors whose rationality differs from state entities be subsumed to this system? Again, the deterrent values of Israel's missile defense remain uncertain. In the end, 
if one looks at the Israelis' experience and their ultimately pragmatic attitude to missile defense, the past controversy inside NATO about the balance between missile defense and nuclear deterrence could be seen as exaggerated and emotively charged.

\section{Misunderstanding \#3.}

This leads to a broader discussion on missile defense and Israel's approach to deterrence in accordance with its strategic culture. A third misunderstanding vis-à-vis Israel's missile defense enterprise is the extent to which it impacts the national strategic culture and, in particular, revises the IDF's traditional proclivity to offense rather than defense. To assume that the successes of Arrow and Iron Dome could rebalance the offense-defense equation in Israel's military posture is misleading because it puts aside substantial parallel developments in the IDF.

At the doctrinal level, there has been extensive discussion that, following the 2006 war with Hezbollah, the IDF was implementing a new warfighting posture that put an emphasis on a fast high-intensity air campaign to defeat the enemy in the early stages of the war. This derives from the so-called "Dahya concept." ${ }^{\prime 6}$

On October 2008, Gadi Eisenkot, then Israeli Northern Commander, declared in an interview with the newspaper, Yedioth Ahronoth, that "what happened in the Dahya quarter in Beirut in 2006 will happen in every village from which Israel is fired on. We will apply disproportionate force on it and cause great damage and destruction there." He went on to say, "From our standpoint, these are not civilian villages, they are military bases." Leaving no space for ambiguity, 
Eisenkot added, "This is not a recommendation. This is a plan. And it has been approved." 69 The speculations were exacerbated further after the IDF conducted Operation CAST LEAD against Hamas in the Gaza Strip from December 27, 2008, to January 18, 2009. In late-2009, a UN mission conducting an investigation into the 2009 Gaza conflict between the IDF and the Palestinian organization, Hamas, concluded that this Dahya strategy had indeed been applied in the Gaza Strip. ${ }^{70}$

Whether or not the Dahya strategy is part of IDF's posture, this debate reflected the fact that the Israeli military was reemphasizing the use of disproportional force as a means of deterrence. In that sense, missile defense systems are merely means to prevent the aggressor from winning the fight with a first wave of its attack, and provide time for an offensive response to be launched. However, it has to be understood in the context of Israel's very particular approach to the concept of deterrence.

Whereas the United States and its Western allies conceive deterrence as a game of threats to prevent open confrontation, Israeli military thinkers do not disconnect it from the conduct of military operations. In fact, deterrence in the Israeli mindset derives from the effectiveness of its military campaigns. It is what some scholars call "cumulative deterrence." Israeli Reserve Major General Doron Almog explains in the journal Parameters:

Unlike classical deterrence as practiced during the Cold War, and whose success hinged on a bipolar standoff that held in check any impulse to launch a nuclear first strike, cumulative deterrence is based on the simultaneous use of threats and military force over the course of an extended conflict. ${ }^{71}$ 
From that perspective, the 2012 and 2014 operations in the Gaza Strip were not understood by the military establishment as a failure of the whole deterrence system, but rather as occasional clashes needed to sustain or to "restore" it. As Avner Golov from Israel's Institute for National Security Studies wrote, "achieving a state of deterrence was a central goal of Operation PILLAR OF DEFENSE, in order to restore calm to the south of Israel. ${ }^{72}$

This means that missile defense only marginally impacts Israel's strategic culture. In fact, developments such as the Dahya concept evidence the on-going return to the original military posture built in the early years of Israel. In that context, missile defense is not a game changer, but a mere complement that widens the array of options for the decisionmaker.

\section{Misunderstanding \#4.}

This leads to the fourth and final lesson from Israel's experience with missile defense, which is its meaning for the United States and its NATO allies. As we discuss here, the political passion that surrounds Iron Dome generates several misunderstandings. As a consequence, the discussion of Israel's missile defense is usually based on a distorted mirror effect. For instance, Karl-Heinz Kamp, the academic director of the federal academy for security policy in Germany and an influential voice in the transatlantic security community, wrote:

the recent confirmation of Iron Dome's reliability was of fundamental importance. In this sense, the implications of its success extend far beyond the Middle East, and will have an impact on the entire Atlantic alliance. $^{73}$ 
The narrative implies that what works (presumably) for Israel will automatically work for NATO.

Indeed, the Atlantic Alliance now looks at Israel's reliance on this form of defense as a possible reflection of how its own posture on the subject is evolving. However, the Israeli analogy is not relevant at the operational level. The first key lesson for NATO planners is that threats driving different actors' military policies are not alike. NATO looks at potential midto long-term challenges that could be posed by ballistic arsenals, whereas Israel sees missiles and rockets as constituting close and immediate "existential" dangers to its territory.

From a NATO perspective, what is at stake is the proliferation of countries with the technical capabilities and the scientific know-how to develop a ballistic missile arsenal. But in the absence of any obvious and indisputable threat, the prudent course is to avoid too specific a focus in current defense efforts. True, the Alliance's contingency scenarios clearly identify the Middle East as the region from which missiles could be fired at NATO territories. In political terms, however, the Alliance has so far made no declarations of a more specific nature on the subject. At the 2010 Lisbon, 2012 Chicago, and 2014 Wales summits, the Allies agreed on an official but rather vague statement that ballistic missiles pose an increasing threat. The difficulty of obtaining a common threat assessment emerges clearly if one considers that some of the 28 member states consider Russia the greatest threat in terms of proliferation, while others do not support the Alliance in identifying Iran as a threat.

From this perspective, the lesson from the Israeli experience is one of caution: the threat assessment driving IDF planning cannot be transposed in identical 
form to NATO. Although all stakeholders recognize that ballistic missiles have proliferated in recent years, NATO is faced with the potential threat of arsenals that, for the most part, are still in the making. ${ }^{74}$ The singular experience of the Israelis with missile defense is definitely worth exploring, but analogies should not be exaggerated. To overcome the current fad with Israel's missile defense, one should remember the words from Bernard Brodie:

that is not to say that effective active defenses against the missile are technically impossible, or that their development should not be pursued; it is only to point out that one must have extraordinary faith in technology, or a despair of alternatives, to depend mainly on active defenses. ${ }^{75}$

\section{CONCLUSION}

The findings of this monograph have implications for both scholars and practitioners. First, the history of Israel's missile defense enterprise is a revealing case on the remaking of a national military posture. It highlights the ways in which new technological systems impact a strategic culture like that of Israel. This case also shows how the development of the Arrow and Iron Dome systems has now become a pillar of U.S.Israel cooperation. With major decisions expected in the future on the continuous funding of these systems, it is worth assessing the role they currently play in Israel's military policy.

But this monograph also aimed at offering a cautious look regarding the strategic added value of missile defense. We underlined how misreading the Israeli experience could lead to wrong analogies and false policy conclusions. The Israeli context is so particular 
that it can hardly be used to reveal similar lessons for NATO and the United States. As we have shown, despite the overblown political passion surrounding the topic, the Israelis never considered that these systems would rebalance their strategic culture from the offense to the defense. This matters for the practitioners in the U.S. national security community as well as in the NATO circles.

The limitations and uncertainties about the strategic effectiveness of Israel's missile defense mentioned before do not discount the value of these systems, but for those decisionmakers and congressmen that closely follow U.S.-Israel cooperation, this means that the United States should be careful not to focus its aid solely on this enterprise, as the annual trends may suggest. In a time of austerity, a discussion on the right mix of resources allocated to U.S. aid to Israel is worth having.

Furthermore, U.S. and NATO decisionmakers should treat the Israeli case prudently. Although the successes of Israeli systems signify the operational relevance of defensive means against ballistic arsenals, they should not be used as leverage in the United States and transatlantic debates over missile defense. As we stressed in our analysis, the only similar type of threat covered by both the NATO and the Israeli projects is the one of long-range or intercontinental ballistic missiles. As of today, this discussion remains primarily speculative because one needs to wait the advancement of the Arrow system to draw concrete lessons from the Israelis.

Despite these caveats, the story of how Israel built one of the most sophisticated missile defense architectures constitutes a precious case for strategic studies as it puts into light the challenges of operating a 
multilayered defense against heterogeneous threats or the complexity of combining missile defense and conventional deterrence. As the story of Israel's missile defense has not yet reached its final chapter, it will be worth following these technical as well as strategic developments in the years to come.

\section{ENDNOTES}

1. Joseph Bermudez, "Ballistic Missiles in the Third World: Egypt and the 1973 Arab-Israeli War," Jane's Intelligence Review, Vol. 3, No. 12, December 1991, p. 537.

2. President Ronald Reagan, "Address to the Nation on Defense and National Security," March 23, 1983, available from www.reagan.utexas.edu/archives/speeches/1983/32383d.htm, accessed on August 25, 2014.

3. Michael Handel, "The Evolution of Israeli Strategy: The Psychology of Insecurity and the Quest for Absolute Security," Williamson Murray, MacGregor Knox, Alvin Bernstein, eds., The Making of Strategy: Rulers, States, and War, Cambridge, UK: Cambridge University Press, 1996, pp. 534-578; Yoov Ben-Horin and Barry Posen, Israel's Strategic Doctrine, Santa Monica, CA: RAND Corporation, 1981.

4. Ariel Levite, Offense and Defense in Israeli Military Doctrine, Boulder, CO: Westview Press, 1989, p. 126.

5. Harry Waldman, The Dictionary of Strategic Defense Initiative, New York: Wilmington, 1988, p. 80.

6. Uzi Eilam, Eilam's Arc: How Israel became a Military Technology Powerhouse, Brighton, Sussex, UK: Academic Press, 2011, pp. 204-241.

7. Ibid., p. 242.

8. Central Intelligence Agency, "Iraqi Ballistic Missile Developments," Memorandum, July 1990. Source: CIA Electronic Reading Room, released under the Freedom of Information Act. 
9. Eytan Gazit, The Middle East Military Balance, Tel Aviv, Israel: Tel Aviv University, 1994, p. 222. Project Babylon components were destroyed in October 1991 under UN supervision.

10. Bernard Rostker, Information Paper Iraq's Scud Ballistic Missiles, July 25, 2000, available from www.iraqwatch.org/government/ US/Pentagon/dodscud.htm, accessed on July 28, 2014.

11. Mitch Ginsburg, "Chinks Rremain in Israel's Air Defense Armor, Despite Iron Dome," Times of Israel, March 14, 2012.

12. Kevin Woods, David Palkki, and Mark Stout, eds., A Survey of Saddam's Audio Files, 1978-2001: Toward an Understanding of Authoritarian Regimes, Alexandria, VA: Institute for Defense Analyses, 2010, p. 259.

13. David Ivri, "Deterrence Is Not Enough. Israel Needs a Multi-Layered Response to the Ballistic Missile Threat," Ramat Gan, Israel: Begin Sadat Center, December 28, 1998, available from www.biu.ac.il/Besa/bulletin/no8art1.htm, accessed July 11, 2014.

14. Interview with a former official from the Israeli Ministry of Defense, Tel Aviv, Israel, February 2012.

15. U.S. Department of State, Report on the Proliferation of Missiles and Essential Components of Nuclear, Biological, Chemical and Radiological Weapons, Washington, DC: U.S. Government Printing Office, April 22, 2009.

16. Michael Flynn, "Current and Future Worldwide Threats," Senate Armed Services Committee Hearing, April 18, 2013, quoted in: Paul K. Kerr, Mary Beth D. Nikitin, and Steven A. Hildreth, Iran-North Korea-Syria Ballistic Missile and Nuclear Cooperation, Washington, DC: Congressional Research Service (CRS), 2014, p. 5.

17. Duncan Lennox, ed., Jane's Strategic Weapons Systems, Surrey, UK: Jane's Information Group, January 2009, p. 176.

18. Steven Hildreth, Iran's Ballistic Missile and Space Launch Programs, CRS Report for Congress, Washington, DC: CRS, 2012, p. 15. 
19. United Nations, Security Council Committee established pursuant to resolution 1737 (2006, Final Report of the Panel of Experts submitted in accordance with Resolution 1984 (2011), S/2012/395, June 12, 2012. The Panel of Experts report was issued under UN Security Council Resolution 1929, which mandated the Panel of Experts. UN Security Council Resolution 1984 renewed the 1929 Panel of Experts mandate.

20. Hildreth, p. 19.

21. International Institute for Strategic Studies, The Military Balance 2012, London, UK: Routledge, 2012, p. 297.

22. William B. Reinckens, "Defense Sec. Cohen, Israeli Defense Minister Discuss Missiles," Federation of American Scientists, March 27, 1998, available from fas.org/spp/starwars/program/ news98/98032703_npo.html, accessed on September 22, 2014.

23. "Israel Ready to Deploy Arrow 2 missile System," Xinhua News Service, May 28, 1998.

24. Reuven Pedatzur, The Arrow System, Memorandum No.42 [in Hebrew], Tel Aviv, Israel: Jaffee Center for Strategic Studies, 1993.

25. Reuven Pedatzur, "The Arrow's Toadies," Haaretz, March $14,2000$.

26. Eilam, p. 213.

27. The Israeli radar can detect missiles up to $150-\mathrm{km}$, while the American one can go up to $900-\mathrm{km}$.

28. Gili Cohen, "U.S., Israel Kick Off Joint Exercise to Train Troops in Battling Missiles," Haaretz, May 18, 2014.

29. Jeremy Sharp, U.S. Foreign Aid to Israel, Washington, DC: CRS, April 11, 2014, p. 10.

30. Nir Shaviv, "How Bad are the Hezbollah Katyusha Rockets," Science Bits, July 27, 2006, available from www.sciencebits.com/ Katyusha, accessed on September 22, 2014. 
31. Quoted in Nicholas Noe, ed., Voice of Hezbollah: The Statements of Sayyed Hassan Nasrallah, London, UK: Verso, 2007, p. 62.

32. Ibid., pp. 348-349.

33. Quoted in Byman, p. 253.

34. William Arkin, "Divine Victory for Whom? Airpower in the 2006 Israel-Hezbollah War," Strategic Studies Quarterly, Vol. 1, No. 2, Winter 2007, p. 99.

35. Benjamin Lambeth, Air Operations in Israel's War against Hezbollah: Learning from Lebanon and Getting It Right in Gaza, Santa Monica, CA: RAND Corporation, 2011, p. XV.

36. Byman, p. 253; Arkin, p. 118.

37. Yoaz Hendel, "Failed Tactical Intelligence in the Lebanon War," Strategic Assessment, Vol. 9, No. 3, November 2006, available from www.inss.org.il/publications.php? cat $=21$ Eincat $=\mathcal{E}$ read $=90$, accessed on June 24, 2013.

38. Gabriel Siboni, "From the Second Intifada through the Second Lebanon War to Operation Cast Lead: Puzzle Pieces of a Single Campaign," Military and Strategic Affairs, Vol. 1, No. 1, April 2009, p. 26.

39. Giora Eiland, "The Third Lebanon War," Strategic Assessment, Vol. 11, No. 2, November 2008, p. 12.

40. Ari Rabinovitch, "Israel's Barak Warns of Growing Hezbollah Arsenal," Reuters, September 10, 2008; Avi Issacharaoff, "Peres: Israel Knows Hezbollah Has 80000 Rockets," Haaretz, August 24, 2009.

41. Interviews conducted by the author with Israeli officers, in Tel Aviv, Israel, February 2012.

42. Charles Levinson and Jay Solomon, "Syria Gave Scuds to Hezbollah, U.S. Says," The Wall Street Journal, April 14, 2010.

43. Quote from Byman, p. 177. 
44. Uzi Rubin, The Missile Threat from Gaza: From Nuisance to Strategic Threat, Tel Aviv, Israel: Begin-Sadat Center for Strategic Studies, 2011, p. 15.

45. Byman, p. 183.

46. Hélène Sallon, "Gaza : quelles sont les capacités militaires du Hamas?" ("Gaza : What Are the Military Capabilities of Hamas?"), Le Monde, July 10, 2014.

47. Benedetta Berti, "Salafi-Jihadi Activism in Gaza: Mapping the Threat," CTC Sentinel, May 2010, Vol. 3, No. 5, p. 5.

48. "Rockets Used By Other Palestinian Groups" Washington, DC: Jewish Policy Center, available from www.jewishpolicycenter. org/prr/groups.php, accessed on September 3, 2014.

49. Yiftah Shapir, "How Many Domes Does Beer Sheva Need?" INSS Insight, August 28, 2011.

50. Peter Dombrowski, Catherine Kelleher, and Eric Auner, "Demystifying Iron Dome," The National Interest, July-August 2013.

51. Reuters, "Israel's David's Sling Missile Shield Unlikely to be Ready in 2015," May 21, 2014.

52. Uzi Rubin, Iron Dome vs Grad Rockets : A Dress Rehearsal for an All-Out War, Perspective Paper No. 173, Ramat Gan, Israel: Begin Sadat Center for Strategic Studies, July 2012.

53. Ibid.

54. Yiftah S. Shapir, "Iron Dome: The Queen of Battle," Shlomo Brom, ed., In the Aftermath of Operation Pillar of Defense, INSS Memorandum No. 124, Tel Aviv, Israel: Institute for National Security Studies, November 2012, p. 45.

55. “77 millions de dollars américains pour le 'Dôme de fer' israélien" ("77 Million American Dollars for Israel's Iron Dome"), Le Monde, May 17, 2012. 
56. Yaakov Lappin, “US, Israel Sign Deal to Continue Financing Iron Dome," Jerusalem Post, March 10, 2014.

57. Taylor Dinerman, "How Israel Learned to Love Missile Defense," National Review, July 17, 2014.

58. See Shlomo Brom, ed., In the Aftermath of Operation Pillar of Defense, Tel Aviv, Israel: Institute for National Security Studies, 2012.

59. "Eizenkot: Rocket Defenses Designed for IDF, Not Citizens," Jerusalem Post, January 12, 2010.

60. Yoav Zitun, "IDF: Iron Dome Intercepted 90\% of Rockets," Ynet News, August 15, 2014.

61. Theodore Postol, "An Explanation of the Evidence of Weaknesses in the Iron Dome Defense System," MIT Technology Review, July 15, 2014.

62. Uzi Rubin, "Israel's Iron Dome Missile-Defense System is an Ironclad Success," Reuters, August 8, 2014.

63. Ibid.

64. "Operation Desert Storm: Data Does Not Exist to Conclusively Say How Well Patriot Performed," Washington, DC: U.S. General Accounting Office, September 1992, pp. 3-4; Theodore A. Postol, "Lessons of the Gulf War Experience with Patriot," International Security, Vol. 16, No. 3, Winter 1991-92, pp. 119-171.

65. Louis Charbonneau and Parisa Hafezi, "Iran Pursues Ballistic Missile Work, Complicating Nuclear Talks," Reuters, May 15, 2014.

66. Charles Levinson and Jay Solomon, "Syria Gave Scuds to Hezbollah, U.S. Says," The Wall Street Journal, April 14, 2010.

67. Bernard Brodie, Strategy in the Missile Age, Princeton, NJ: Princeton University Press, 1959, p. 202. 
68. Jean-Loup Samaan, "The 'Dahya Concept' and Israeli Military Posture vis-a-vis Hezbollah since 2006," Comparative Strategy, Spring 2013.

69. "Israel Warns Hezbollah War Would Invite Destruction," Yedioth Ahronoth, October 3, 2008, available from www.ynetnews. com/articles/0,7340,L-3604893,00.html, accessed on September 22, 2014.

70. United Nations Human Rights Council, Report of the United Nations Fact Finding Mission on the Gaza Conflict, New York: United Nations, September 15, 2009, p. 331, available from www2.ohchr. org/english/bodies/hrcouncil/specialsession/9/docs/unffmgc_report.pdf, accessed on September 22, 2014.

71. Doron Almog, "Cumulative Deterrence and the War on Terrorism," Parameters, Vol. 34, No. 1, Winter 2004-2005, pp. $4-19$, p. 8 .

72. Avner Golov, "The Campaign to Restore Israeli Deterrence," Shlomo Brom, ed., In the Aftermath of Operation Pillar of Defense, Tel Aviv, Israel: Institute for National Security Studies, 2012, p. 23.

73. Karl-Heinz Kamp, "Missile Defense is Feasible," Security Times, February 2013.

74. Jean-Loup Samaan and Guillaume Lasconjarias, "The Israeli Experience in Missile Defense: Lessons for NATO," Washington, DC: Atlantic Council, Brent Scowcroft Center, August 2013.

75. Brodie, p. 221. 


\title{
U.S. ARMY WAR COLLEGE
}

\author{
Major General William E. Rapp \\ Commandant
}

\section{***** \\ STRATEGIC STUDIES INSTITUTE and U.S. ARMY WAR COLLEGE PRESS}

Director

Professor Douglas C. Lovelace, Jr.

Director of Research

Dr. Steven K. Metz

\begin{abstract}
Author
Dr. Jean-Loup Samaan

Editor for Production

Dr. James G. Pierce

Publications Assistant

Ms. Rita A. Rummel
\end{abstract}

*****

Composition

Mrs. Jennifer E. Nevil 


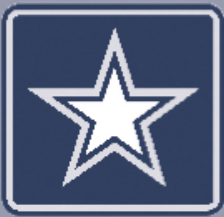

\section{U.S.ABMTY}

THE

UNITED STATES

ARMY WAR COLLEGE

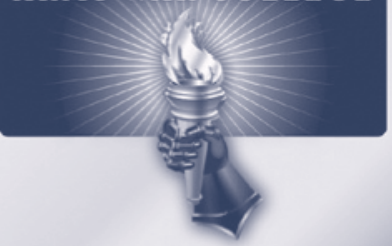

STR ENGTH $\approx$ W ISDOM

FOR THIS AND OTHER PUBLICATIONS, VISIT US AT http://www.carlisle.army.mil/

ISBN 1-58487-675-1

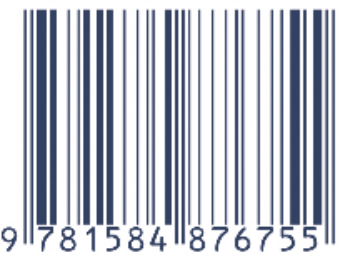

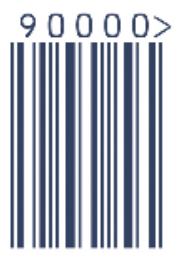

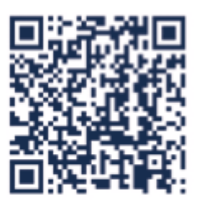

This Publication

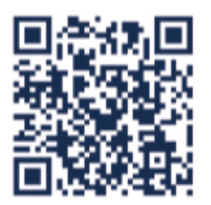

口回证回

SSI Wensite

USAWC Website 